\title{
MODELS OF FACTORS DRIVING THE CZECH EXPORT
}

\author{
David Havrlant, Roman Hušek*
}

\begin{abstract}
This paper aims to analyze the cost factors that influence the export of the Czech Republic, and to estimate models suitable for quantitative analysis of export and its prediction. According to the macroeconomic theory, the fundamental export factors include foreign demand, domestic and foreign price level and exchange rate. Foreign demand reflects the business cycle of foreign economy, price levels and exchange rate characterize the competitiveness of the exported goods, and the exchange rate determines, among others, the production costs through the prices of imported crucial inputs. Several models are applied to set of these variables, and their impact on the export dynamics of the Czech Republic is evaluated.
\end{abstract}

Keywords: export, exchange rate, import, producer and energy prices, VECM, cointegration analysis

JEL Classification: C22, C53, F47

\section{Introduction}

For a small and open economy the export represents not only an opportunity to join the international market with all the well known benefits it brings, but it is indeed an important economic stimulus, since it comprises a significant component of the country's gross domestic product (GDP). In case of the Czech Republic (CR) the volume of exports is comparable with the total GDP of CR even in the long term, and its contribution to the year-on-year GDP growth has come up to $30 \%$ on average since 2006. All of these are the typical features of an export oriented economy (Zweimüller, 2001).

This paper aims to analyze the cost factors that influence the export of the Czech Republic, and to estimate models suitable for quantitative analysis of export and its prediction. According to the macroeconomic theory, the fundamental export factors

* David Havrlant, Czech National Bank (david.havrlant@cnb.cz); Roman Hušek, University of

Economics, Prague (husek@vse.cz); this paper was written with the support of the GA 402/09/0273

Grant from the Czech Science Foundation. 
include foreign demand, home and foreign price levels and exchange rate. Foreign demand reflects the business cycle of foreign economy, price levels and exchange rate characterize the competitiveness of the goods to be exported, and the exchange rate determines, among others, the production costs through the prices of imported crucial inputs. Some papers concerning this topic have been already published; see for example Pánková (2003), Nešvera (2006) or Rojíček (2010).

The analysis is carried out on the data set 1996Q1-2010Q2 on data with quarterly frequency. Nevertheless in some cases the estimation range differs slightly. The series are tested for stationarity, and the test outcomes indicate that the time series are mostly integrated of order one (Greene, 2003), thus a cointegration approach is applied. When necessary, the time series have been seasonally adjusted. The data used in this work were obtained from the Czech Statistical Office, the Czech National Bank and the Eurostat.

\section{Foreign Demand}

The most important factor for the development of export is foreign demand, because if the consumer sentiment abroad weakens noticeably, the export production usually cumulates in stocks, and that leads to output reductions as well as to the lowering of production capacities in the long run. For example at the beginning of 2009 many car producers had to store some part of their production on testing circuits, giving up the possibility of testing, because they were forced by unexpectedly weak demand. It is obvious that boom or recession is nowadays a globalized phenomenon which influences all markets in a very short time. Regarding the main trade partners of the Czech Republic the dynamics of foreign demand is approximated by the GDP development of the European Union (EU). The following figure shows the quarter on quarter dynamics of Czech export ( $X$, on the left axis), foreign GDP (GDPEMU) and home GDP (GDP) in the period 1996Q1-2010Q2.

Figure 1

Czech Export (X), Foreign GDP (GDPEMU) and Home GDP (GDP), q-o-q in \%

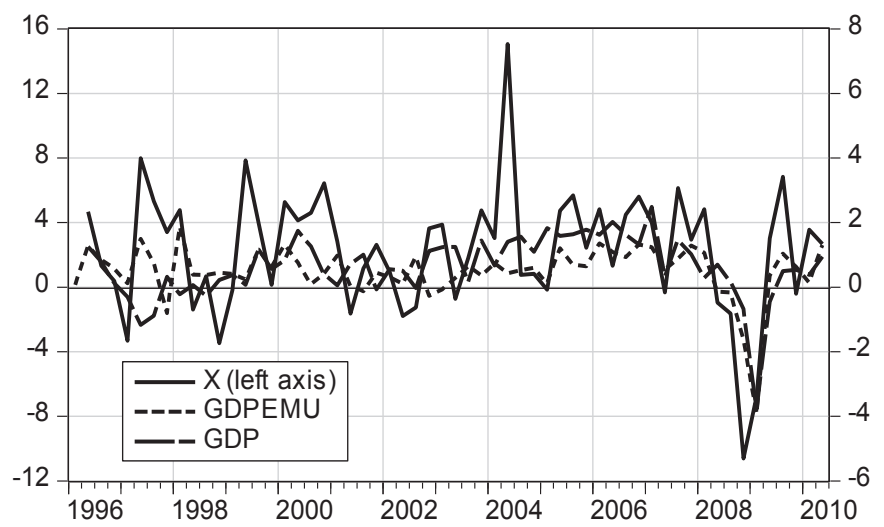

It is obvious that Czech export and foreign GDP are closely related quantities. This proves the positive correlation coefficient as well. The reaction of Czech export comes shortly after changes in foreign demand. The correlation coefficient of export 
and home GDP is positive as well - the net export makes up a substantial part of the Czech GDP, and the relation is assumed to possess attributes of rather market driven economy.

Table 1

Correlation Coefficient of Export (X), Foreign GDP (GDPEMU) and Home GDP (GDP), q-o-q in \%

\begin{tabular}{|l|l|c|c|}
\hline Correlation & $\mathbf{X}$ & GDPEMU & GDP \\
\hline $\mathbf{X}$ & 1.0 & & \\
\hline GDPEMU & 0.6 & 1.0 & \\
\hline GDP & 0.4 & 0.5 & 1.0 \\
\hline
\end{tabular}

\section{Cost Factors and Exchange Rate}

Cost factors play a substantial role in the dynamics of export on the one hand and the exchange rate on the other hand. The lower the price of exported goods is in comparison with the price of similar product abroad, the more favourable are the arbitrage opportunities. The price of exported goods in foreign currency is then determined by the nominal exchange rate. The more the nominal exchange rate appreciates, the higher is the price of the exported commodity in foreign currency, and that decreases the profit of arbitrage (Rogoff, 1996). It is necessary to investigate both - the influence of the prices and the effect of the exchange rate. The figure bellow shows the quarteron-quarter growth rate of export ( $X$, on the left axis), nominal exchange rate with one quarter lag $(E U R(-1))$ and domestic producer prices with lag of two quarters $(P P I(-2))$.

Figure 2

Export (X), Producer Prices (PPI) and Exchange Rate (EUR), q-o-q in \%

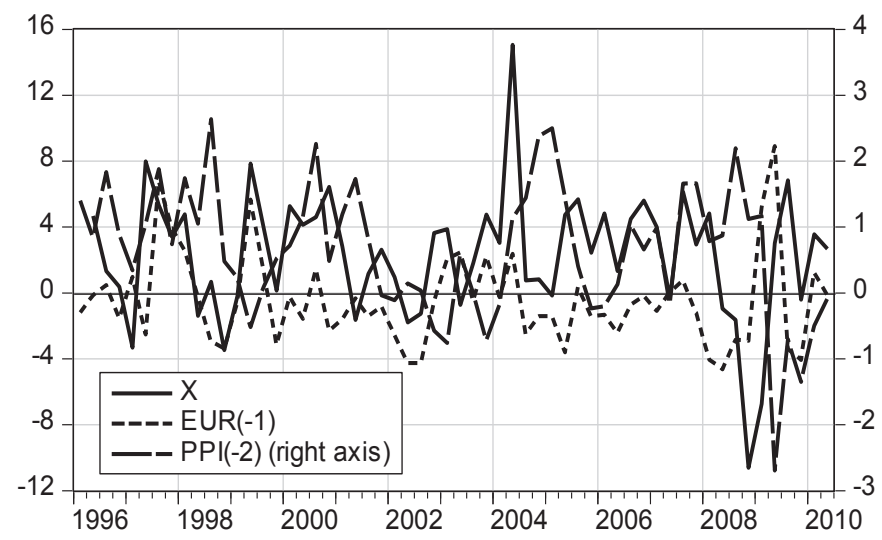

It is obvious that the exchange rate appreciation usually leads to decline in exports and depreciation evokes export growth. This relation of export and exchange rate corresponds with theoretical assumptions, while appreciation increases foreign prices of exported products and dampens the advantage of arbitrage. The lag length in which the exchange rate fluctuations most influence the dynamics of export is one quarter. 
It is very likely that the producer prices influence the swings of export with a lag, which is caused by the long-term character of contracts and to some extent by the reserves of key materials. In that case the theoretical assumption would hold: the drop of domestic prices would lead to an increase in the export activity, though with lag of two quarters. The following chart shows correlation coefficients of export $(X)$, exchange rate with one quarter lag $(E U R(-1))$ and producer prices with a two quarters lag $($ PPI(-2)). For more detail see Frenkel (1981).

Table 2

Correlation Coefficient of Export (X), Exchange Rate (EUR) and Producer Prices (PPI), q-o-q in \%

\begin{tabular}{|l|c|c|c|}
\hline Correlation & $\mathbf{X}$ & EUR(-1) & PPI(-2) \\
\hline $\mathbf{X}, \mathbf{q}-\mathbf{0 - q}$ & 1.00 & & \\
\hline EUR(-1), q-o-q & 0.3 & 1.00 & \\
\hline PPI(-2), q-o-q & -0.3 & -0.2 & 1.00 \\
\hline
\end{tabular}

\subsection{Producer Prices}

Producer prices in a small open economy $(P P I)$ are strongly related to the prices of imported semi-finished products and both energy and non-energy materials, which are determined by the price development on the world markets. These are again adjusted by the exchange rate. Some relations are pictured in the following figure. The world prices of semi-finished products are represented by the producer prices in the European Union (PPIEMU). Their high growth is usually moderated by the movements of exchange rate $(E U R)$. The data in following exploration are available for the period 1996Q1-2010Q2 on quarterly basis.

Figure 3

Domestic and Foreign Producer Prices and Exchange Rate, q-o-q in \%

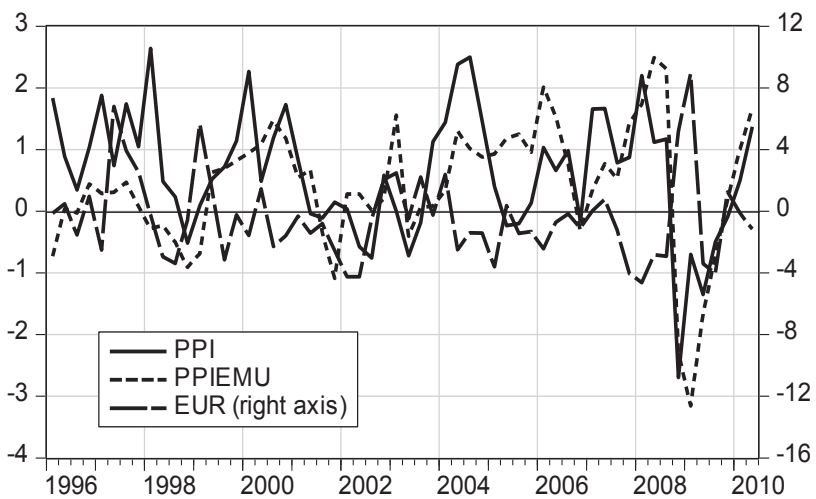

A brief analysis of logarithms of the data in levels indicates, that the original time series possess a stochastic trend, i. e. they are non-stationary, as performed unit-root tests suggest (Elliott, 1996 or Enders, 2004). In the table below the results of Augmented Dickey-Fuller test (ADF, Dickey and Fuller, 1979) are summarized, and 
provide sufficient evidence, for it is not possible to reject the null hypothesis of unit root on reasonable significance level for all tested series. The ADF test is made under assumption of individual intercept and trend for examined series, and the lag length selection is based on modified Schwartz information criterion (SC, Davidson and MacKinnon, 2004). Nevertheless use of different lag length criteria (Akaike, 1969, Hannan-Quinn, 1979) leads to similar outcome.

Particularly the time series are integrated of order one, i. e. I(1), as the ADF test of first differences in Table 3 proves, since it is possible to reject the null hypothesis of unit root on reasonable significance level for all examined series. The asterisk denotes rejection of the null hypothesis at the $5 \%$ level of significance. The ADF test is made under precondition of individual intercept, while the trend is assumed to be eliminated by differencing. The lag length selection is again based on modified SC. Nevertheless use of other lag length criteria leads to similar conclusion.

Table 3

Stationarity Test of the Logarithms of the Original Time Series and of the First Differences

\begin{tabular}{|l|c|c|l|c|c|}
\hline Series & Prob. & Lag & \multicolumn{1}{|c|}{ Series } & Prob. & Lag \\
\hline LOG(PPIPRO) & 0.673 & 1 & D(LOG(PPIPRO)) & $0.002^{*}$ & 3 \\
\hline LOG(EUR) & 0.349 & 0 & D(LOG(EUR)) & $0.000^{*}$ & 2 \\
\hline LOG(USD) & 0.668 & 0 & D(LOG(USD)) & $0.000^{*}$ & 3 \\
\hline LOG(PPIEMU) & 0.436 & 1 & D(LOG(PPIEMU)) & $0.004^{*}$ & 2 \\
\hline LOG(BRENT) & 0.421 & 0 & D(LOG(BRENT)) & $0.000^{*}$ & 2 \\
\hline
\end{tabular}

Consequently, the first differences of logarithms of the original data can be considered to be stationary, $i$. e. their mean and variance is expected to be constant over time (Wooldridge, 2002). When a regression on this data is carried out, there is no need to be afraid of spurious regression (Granger and Newbold, 1974) or of the heteroskedasticity problem.

Regarding the Granger causality (Geweke, 1984) with emphasis on domestic producer prices (PPIPRO), the significance of relations among the variables is included in the next table. It is obvious that the relations and their directions are in line with economic intuition and with the later analysis (reject the null hypothesis on reasonable level of significance in Table 4), except the case of relation between the exchange rate $\mathrm{CZK} / \mathrm{EUR}$ and the domestic producer prices. This outcome would rather validate, that the change in domestic prices precedes the change in exchange rate. 
Table 4

Granger Causality regarding PPIPRO

\begin{tabular}{|l|c|c|}
\hline Null Hypothesis: & F-Statistic & Prob. \\
\hline LOG(EUR) does not Granger Cause LOG(PPIPRO) & 0.582 & 0.628 \\
\hline LOG(PPIPRO) does not Granger Cause LOG(EUR) & 6.046 & $0.001^{*}$ \\
\hline LOG(USD) does not Granger Cause LOG(PPIPRO) & 2.514 & $0.041^{*}$ \\
\hline LOG(PPIPRO) does not Granger Cause LOG(USD) & 1.143 & 0.334 \\
\hline LOG(PPIEMU) does not Granger Cause LOG(PPIPRO) & 3.270 & $0.023^{*}$ \\
\hline LOG(PPIPRO) does not Granger Cause LOG(PPIEMU) & 0.765 & 0.516 \\
\hline LOG(BRENT) does not Granger Cause LOG(PPIPRO) & 10.495 & $0.000^{*}$ \\
\hline LOG(PPIPRO) does not Granger Cause LOG(BRENT) & 0.168 & 0.918 \\
\hline
\end{tabular}

The appropriate lag length used for Granger causality exploration was adjusted in line with the Akaike information criterion (AIC, Akaike, 1969), Schwartz information criterion (SC) and Hannan-Quinn criterion (HQ, Hannan and Quinn, 1979), as it is summarized in Table 5. The asterisk denotes the appropriate lag length.

Table 5

Appropriate Lag Length Selection

\begin{tabular}{|l|l|l|l|}
\hline Lag & AIC & SC & HQ \\
\hline $\mathbf{0}$ & -13.4 & -13.3 & -13.4 \\
\hline $\mathbf{1}$ & -29.2 & $-28.6^{*}$ & -29.0 \\
\hline $\mathbf{2}$ & -29.5 & -28.3 & $-29.0^{*}$ \\
\hline $\mathbf{3}$ & -29.4 & -27.7 & -28.7 \\
\hline $\mathbf{4}$ & $-29.50^{*}$ & -27.3 & -28.6 \\
\hline $\mathbf{5}$ & -29.5 & -26.7 & -28.3 \\
\hline $\mathbf{6}$ & -29.3 & -26.0 & -28.0 \\
\hline
\end{tabular}

As all the series are of the same integration order, particularity I(1), the long-run dynamics could be inspected within the vector error correction model (VECM, see Greene, 2003), thus some prior exploration of cointegration is necessary, so the Johansen cointegration test (Johansen, 1988) is carried out onward. Under the condition of intercept and trend the trace test as well as the maximum eigenvalue statistics gives the same rank of cointegration (Johansen, Juselius, 1990), as shown in Table 6. The asterisk denotes rejection of the null hypothesis at the $5 \%$ level of significance.

Table 6

Cointegration Rank Test (Trace and Maximum Eigenvalue)

\begin{tabular}{|l|c|c|c|c|r|r|r|}
\hline $\begin{array}{l}\text { Number of hypothesized } \\
\text { cointegrating relations }\end{array}$ & $\begin{array}{c}\text { Eigen- } \\
\text { value }\end{array}$ & $\begin{array}{c}\text { Trace } \\
\text { Statistic }\end{array}$ & $\begin{array}{l}\text { Critical } \\
\text { Value }\end{array}$ & Prob. & $\begin{array}{c}\text { Max-Eigen. } \\
\text { Statistic }\end{array}$ & $\begin{array}{l}\text { Critical } \\
\text { Value }\end{array}$ & Prob. \\
\hline None* & 0.279 & 76.559 & 69.819 & $0.013^{*}$ & 47.339 & 33.877 & $0.001^{*}$ \\
\hline At most 1 & 0.096 & 29.220 & 47.856 & 0.758 & 14.685 & 27.584 & 0.773 \\
\hline At most 2 & 0.067 & 14.535 & 29.797 & 0.809 & 10.030 & 21.132 & 0.742 \\
\hline At most 3 & 0.024 & 4.505 & 15.495 & 0.859 & 3.473 & 14.265 & 0.910 \\
\hline At most 4 & 0.007 & 1.031 & 3.841 & 0.310 & 1.031 & 3.841 & 0.310 \\
\hline
\end{tabular}


Both tests reject the null hypothesis of none cointegration rank on reasonable level of significance, and do not reject the null hypothesis of at most one cointegration rank at the same time, thus one cointegration relation that describes the long-run dynamics of the system can be found. Since the time series are cointegrated, the Granger causality can be tested on levels. It is assumed that the exogenity conditions hold. The lag length used in VECM estimation is adjusted in line with SC (Table 5), and the numerical results regarding domestic producer prices (PPIPRO) are shown below.

$\hat{\mathrm{D}}($ LOG(PPIPRO) $)=-0.148 *(\operatorname{LOG}($ PPIPRO(-1) $)-0.724 *$ LOG(PPIEMU(-1)) -

$-0.231 * \operatorname{LOG}(\operatorname{EUR}(-1))-0.070 * \operatorname{LOG}(\operatorname{BRENT}(-1))-0.041 * \operatorname{LOG}(\mathrm{USD}(-1)))+$

$+0.587 * \mathrm{D}(\operatorname{LOG}(\operatorname{PPIPRO}(-1)))-0.113 * \mathrm{D}(\operatorname{LOG}(\operatorname{PPIEMU}(-1)))+0.109 * \mathrm{D}(\operatorname{LOG}(\operatorname{EUR}(-1)))+$

$+0.015 * \mathrm{D}(\operatorname{LOG}(\operatorname{BRENT}(-1)))-0.039 * \mathrm{D}(\operatorname{LOG}(\operatorname{USD}(-1)))$

where the first non differenced terms express the long-run relationship. Their statistical attributes are in the following table, where the standard errors are in brackets and $t$-statistics follow. The asterisk denotes rejection of the null hypothesis at the $10 \%$ level of significance.

Table 7

Cointegrating Vector

\begin{tabular}{|l|c|}
\hline LOG(PPIPRO(-1)) & 1.000 \\
\hline LOG(PPIEMU(-1)) & $-0.724^{*}$ \\
& $(0.061)$ \\
& {$[-12.061]$} \\
\hline LOG(EUR(-1)) & $-0.231^{\star}$ \\
& $(0.081)$ \\
& {$[-2.856]$} \\
\hline LOG(BRENT(-1)) & $-0.070^{*}$ \\
& $(0.020)$ \\
& {$[-3.473]$} \\
\hline LOG(USD(-1)) & -0.041 \\
& $(0.031)$ \\
& {$[-1.298]$} \\
\hline
\end{tabular}

Table 8

Error Correction Mechanism

\begin{tabular}{|l|c|}
\hline CointEq1 & $-0.148^{*}$ \\
& $(0.076)$ \\
& {$[-1.949]$} \\
\hline D(LOG(PPIPRO(-1))) & $0.587^{*}$ \\
& $(0.154)$ \\
& {$[3.806]$} \\
\hline D(LOG(PPIEMU(-1))) & -0.113 \\
& $(0.187)$ \\
& {$[-0.604]$} \\
\hline D(LOG(EUR(-1))) & $0.109^{*}$ \\
& $(0.068)$ \\
& {$[1.603]$} \\
\hline D(LOG(BRENT(-1))) & $0.015^{*}$ \\
& $(0.008)$ \\
& {$[1.875]$} \\
\hline D(LOG(USD(-1))) & -0.039 \\
& $(0.031)$ \\
& {$[-1.248]$} \\
\hline
\end{tabular}

The short-term dynamics, i. e. the error correction mechanism, is summarized in Table 8 including standard errors and $t$-statistics.

The model proves a $47 \%$ correspondence with the data $(R$-squared $=0,471)$, and is overall statistically significant $(F$-statistic $=8,024)$. The next figure shows the contributions of exogenous variables to the estimated year-on-year growth rates of domestic producer prices. 


\subsection{Import Prices}

The prices of imported semi-finished products, i. e. the import prices excluding energy and food prices $(D C A D J)$, are on the one hand determined by the price development on world markets and by exchange rate dynamics on the other hand. Moreover, they are significantly influenced through world energy prices, especially in times of their high volatility. Consequently a curtail roll in the examination of import prices (excluding energy and food) will play the world prices of semi-finished products in form of producer prices in the European Union (PPIEMU), the world energy prices represented by the prices of crude oil in USD/barrel (BRENT) and the exchange rate of the main business partner CZK/EUR (EUR). The succeeding analysis of import prices is carried out on data for the period 1998M1-2010M3 that is available in monthly frequency.

A quick view on the logarithms of the original time series indicates that all mentioned series are non-stationary as the ADF test in next table proves. The ADF test provides sufficient evidence of non-stationarity, because it is not possible to reject the null hypothesis of unit root on reasonable significance level for all tested series. The ADF test is carried out under assumption of individual intercept and trend for examined series, and the appropriate lag length is selected line with modified SC. Use of different lag length criteria (AIC, HQ) leads to similar outcome.

As the ADF test of the first differenced logarithms of mentioned time series shows, they are integrated of order one, for it is possible to reject the null hypothesis of unit root on reasonable significance level (Table 9). The asterisk denotes rejection of the null hypothesis at the $5 \%$ level of significance. The ADF test is made under assumption of individual intercept, for the trend is assumed to be eliminated by differencing. The lag length selection is again based on modified SC, nevertheless use of other lag length criteria leads to similar conclusion.

Table 9

Stationarity Test of the Logarithms of the Original Time Series and of the First Differences

\begin{tabular}{|l|c|c|l|c|c|}
\hline Series & Prob. & Lag & \multicolumn{1}{|c|}{ Series } & Prob. & Lag \\
\hline LOG(DCADJ) & 0.553 & 1 & D(LOG(DCADJ)) & $0.001^{*}$ & 4 \\
\hline LOG(EUR) & 0.349 & 0 & D(LOG(EUR)) & $0.000^{*}$ & 2 \\
\hline LOG(USD) & 0.668 & 0 & D(LOG(USD)) & $0.000^{*}$ & 3 \\
\hline LOG(PPIEMU) & 0.436 & 1 & D(LOG(PPIEMU)) & $0.004^{*}$ & 2 \\
\hline LOG(BRENT) & 0.421 & 0 & D(LOG(BRENT)) & $0.000^{*}$ & 2 \\
\hline
\end{tabular}

Thus the first differences of logarithms of the original time series can be regarded as stationary, i. e. their mean and variance are assumed to be constant over time. When a regression on this data set is carried out, there is no jeopardy of spurious regression or of the heteroskedasticity problem.

According to the Granger causality with emphasis on the import prices excluding energy and food prices $(D C A D J)$, the significance and direction of relations among variables is summarized in Table 10. The asterisk denotes rejection of the null hypothesis at the $10 \%$ level of significance. Outlined relations and their directions seem to be in line with economic intuition and with onward analysis as well (reject the null hypothesis in the first column on reasonable significance level). 
Table 10

Granger Causality regarding DCADJ

\begin{tabular}{|l|c|c|}
\hline Null Hypothesis: & F-Statistic & Prob. \\
\hline LOG(EUR) does not Granger Cause LOG(DCADJ) & 3.156 & $0.004^{*}$ \\
\hline LOG(DCADJ) does not Granger Cause LOG(EUR) & 2.828 & $0.009^{*}$ \\
\hline LOG(USD) does not Granger Cause LOG(DCADJ) & 1.780 & $0.090^{*}$ \\
\hline LOG(DCADJ) does not Granger Cause LOG(USD) & 1.105 & 0.364 \\
\hline LOG(PPIEMU) does not Granger Cause LOG(DCADJ) & 4.109 & $0.000^{*}$ \\
\hline LOG(DCADJ) does not Granger Cause LOG(PPIEMU) & 1.742 & 0.105 \\
\hline LOG(BRENT) does not Granger Cause LOG(DCADJ) & 2.151 & $0.043^{*}$ \\
\hline LOG(DCADJ) does not Granger Cause LOG(BRENT) & 1.143 & 0.341 \\
\hline
\end{tabular}

The lag length used in computation of the Granger causality statistics was derived from AIC, SC and HQ, but as it is shown in Table 11, the suggestions are quite distinct. The asterisk denotes the appropriate lag length.

Table 11

Appropriate Lag Length Selection

\begin{tabular}{|l|l|l|l|}
\hline Lag & AIC & SC & HQ \\
\hline $\mathbf{0}$ & -13.3 & -13.2 & -13.3 \\
\hline $\mathbf{1}$ & -29.1 & $-28.4^{*}$ & $-28.8^{*}$ \\
\hline $\mathbf{2}$ & -29.1 & -27.9 & -28.6 \\
\hline $\mathbf{3}$ & -29.0 & -27.3 & -28.3 \\
\hline $\mathbf{4}$ & -29.1 & -26.9 & -28.2 \\
\hline $\mathbf{5}$ & $-29.1^{*}$ & -26.4 & -28.0 \\
\hline $\mathbf{6}$ & -28.9 & -25.7 & -27.6 \\
\hline
\end{tabular}

As the examined time series are of the same integration order, particularity I(1), the long-run relation could be again explored within the VECM. Consequently a prior cointegration analysis follows, so the Johansen cointegration test is carried out further. Under the condition of intercept and trend the trace test as well as the maximum eigenvalue statistics concludes that there are two cointegration relations, as shown in Table 12. The asterisk denotes rejection of the null hypothesis at the $5 \%$ level of significance.

Table 12

Cointegration Rank Test (Trace and Maximum Eigenvalue)

\begin{tabular}{|l|l|r|r|r|r|r|l|}
\hline $\begin{array}{l}\text { Number of } \\
\text { hypothesized } \\
\text { cointegrating relations }\end{array}$ & Eigenvalue & $\begin{array}{c}\text { Trace } \\
\text { Statistic }\end{array}$ & $\begin{array}{l}\text { Critical } \\
\text { Value }\end{array}$ & Prob. & $\begin{array}{c}\text { Max-Eigen. } \\
\text { Statistic }\end{array}$ & $\begin{array}{l}\text { Critical } \\
\text { Value }\end{array}$ & Prob. \\
\hline None * & 0.268 & 112.172 & 88.804 & $0.000^{*}$ & 44.997 & 38.331 & $0.007^{*}$ \\
\hline At most 1 * & 0.237 & 67.175 & 63.876 & $0.026^{*}$ & 38.901 & 32.118 & $0.006^{*}$ \\
\hline At most 2 & 0.087 & 28.274 & 42.915 & 0.606 & 13.107 & 25.823 & 0.795 \\
\hline At most 3 & 0.068 & 15.167 & 25.872 & 0.561 & 10.169 & 19.387 & 0.601 \\
\hline At most 4 & 0.034 & 4.997 & 12.518 & 0.597 & 4.997 & 12.518 & 0.597 \\
\hline
\end{tabular}


Nevertheless, the trace test does not reject the null hypothesis that there is at most one cointegrating relation at $1 \%$ significance level. If the assumption of trend occurrence in the original time series is left out - what could be a point of discussion while dealing with price levels - then there remains only one cointegrating relation among the variables as shown in the table below.

Table 13

Cointegration Rank Test (Trace and Maximum Eigenvalue)

\begin{tabular}{|l|c|c|c|c|c|c|c|}
\hline $\begin{array}{l}\text { Number of } \\
\text { hypothesized } \\
\text { cointegrating relations }\end{array}$ & Eigenvalue & $\begin{array}{c}\text { Trace } \\
\text { Statistic }\end{array}$ & $\begin{array}{l}\text { Critical } \\
\text { Value }\end{array}$ & Prob. & $\begin{array}{c}\text { Max-Eigen. } \\
\text { Statistic }\end{array}$ & $\begin{array}{c}\text { Critical } \\
\text { Value }\end{array}$ & Prob. \\
\hline None * & 0.245 & 81.600 & 69.819 & $0.004^{*}$ & 40.484 & 33.877 & $0.007^{*}$ \\
\hline At most 1 & 0.144 & 41.116 & 47.856 & 0.185 & 22.333 & 27.584 & 0.204 \\
\hline At most 2 & 0.072 & 18.783 & 29.797 & 0.509 & 10.762 & 21.132 & 0.671 \\
\hline At most 3 & 0.049 & 8.021 & 15.495 & 0.463 & 7.198 & 14.265 & 0.466 \\
\hline At most 4 & 0.006 & 0.823 & 3.841 & 0.364 & 0.823 & 3.841 & 0.364 \\
\hline
\end{tabular}

It is important to emphasize that there is not such straightforward cointegrating relation if any of the variables from the original data set is excluded, i. e. the whole set of examined time series (DCADJ, EUR, USD, PPIEMU and BRENT) embodies a comprehensible cointegrating relation, moreover in line with economic intuition. Likewise an arbitrary pair of variables from the whole set does not seem to be cointegrated. This information is summarized in the next table where the p-values of the cointegration rank test (trace test) are shown. For selected subsets of variables it is possible to judge their cointegration dispositions when the null hypothesis in the left column is rejected accordingly to the relevant $p$-value. The outcome for the maximum eigenvalue statistics is similar. The asterisk denotes rejection of the null hypothesis at the $5 \%$ level of significance.

Table 14

Cointegration Relations of Selected Subsets of Variables

\begin{tabular}{|l|c|c|c|c|c|c|c|c|c|}
\hline & \multicolumn{7}{|c|}{ Subset of variables and relevant p-values of trace test } \\
\hline & $\begin{array}{c}\text { DCADJ } \\
\text { EUR } \\
\text { Coint. } \\
\text { relations }\end{array}$ & $\begin{array}{c}\text { USD } \\
\text { PPIEMU } \\
\text { EUR } \\
\text { USD } \\
\text { BRENT }\end{array}$ & $\begin{array}{c}\text { DCADJ } \\
\text { EUR } \\
\text { PPIEMU } \\
\text { BRENT }\end{array}$ & $\begin{array}{c}\text { DCADJ } \\
\text { USD } \\
\text { PPIEMU } \\
\text { BRENT }\end{array}$ & $\begin{array}{c}\text { DCADJ } \\
\text { EUR } \\
\text { USD }\end{array}$ & $\begin{array}{c}\text { DCADJ } \\
\text { EUR } \\
\text { PPIEMU }\end{array}$ & $\begin{array}{c}\text { DCADJ } \\
\text { USD } \\
\text { PPIEMU }\end{array}$ & $\begin{array}{c}\text { DCADJ } \\
\text { EUR } \\
\text { BRENT }\end{array}$ & $\begin{array}{l}\text { DCADJ } \\
\text { USD } \\
\text { BRENT }\end{array}$ \\
\hline None & 0.424 & $0.000^{*}$ & $0.000^{*}$ & $0.000^{*}$ & 0.802 & 0.438 & 0.791 & $0.000^{*}$ & 0.663 \\
\hline At most 1 & 0.852 & 0.512 & $0.049^{*}$ & 0.480 & 0.802 & 0.875 & 0.652 & 0.242 & 0.915 \\
\hline At most 2 & 0.674 & 0.691 & 0.438 & 0.658 & 0.831 & 0.685 & 0.620 & 0.524 & 0.723 \\
\hline At most 3 & 0.647 & 0.494 & 0.777 & 0.468 & & & & & \\
\hline
\end{tabular}

To sum up, it can be assumed that there is one straightforward cointegration relation among the whole set of considered time series, so the long-run dynamics of the system can be estimated within a VECM. The time series are cointegrated so, the Granger causality can be tested on levels. It is assumed that the exogenity conditions 
are fulfilled. The lag length used in VECM estimation is adjusted in line with the SC (Table 11), and the numerical results regarding the import prices excluding food and energy $(D C A D J)$ are presented below.

$\hat{\mathrm{D}}(\operatorname{LOG}(\mathrm{DCADJ}))=-0.032 *(\operatorname{LOG}(\operatorname{DCADJ}(-1))-0.581 * \operatorname{LOG}($ EUR(-1) $)-$

$-0.201 * \operatorname{LOG}(\operatorname{USD}(-1))+1.473 * \operatorname{LOG}($ PPIEMU(-1)) $-0.335 * \operatorname{LOG}($ BRENT(-1)) -7.649$)+$

$+0.287 * \mathrm{D}(\operatorname{LOG}(\mathrm{DCADJ}(-1)))+0.038 * \mathrm{D}(\operatorname{LOG}(\operatorname{EUR}(-1)))-$

$-0.015 * \mathrm{D}(\operatorname{LOG}(\operatorname{USD}(-1)))-0.217 * \mathrm{D}(\operatorname{LOG}(\operatorname{PPIEMU}(-1)))-0.013 * \mathrm{D}(\operatorname{LOG}(\operatorname{BRENT}(-1)))$

The first non differenced terms express the long-run dynamics. Their statistical attributes are in the following table, where the standard errors are in brackets and $t$-statistics follow.

Table 15

Cointegrating Vector

\begin{tabular}{|l|c|}
\hline LOG(DCADJ(-1)) & 1.000 \\
\hline LOG(PPIEMU(-1)) & $-0.521^{*}$ \\
& $(0.079)$ \\
& {$[-6.587]$} \\
\hline LOG(EUR(-1)) & $-0.400^{*}$ \\
& $(0.100)$ \\
& {$[-3.972]$} \\
\hline LOG(BRENT(-1)) & -0.014 \\
& 0.026 \\
& {$[-0.523]$} \\
\hline LOG(USD(-1)) & $-0.228^{*}$ \\
& 0.036 \\
& {$[-6.336]$} \\
\hline
\end{tabular}

Table 16

Error Correction Mechanism

\begin{tabular}{|l|c|}
\hline CointEq1 & $-0.472^{*}$ \\
& $(0.139)$ \\
& {$[-3.380]$} \\
\hline D(LOG(DCADJ(-1))) & $0.759^{*}$ \\
& $(0.254)$ \\
& {$[2.978]$} \\
\hline D(LOG(PPIEMU(-1))) & $0.735^{*}$ \\
& $(0.313)$ \\
& {$[2.347]$} \\
\hline D(LOG(EUR(-1))) & -0.155 \\
& $(0.153)$ \\
& {$[-1.013]$} \\
\hline D(LOG(BRENT(-1))) & $-0.041^{*}$ \\
& $(0.018)$ \\
& {$[-2.194]$} \\
\hline D(LOG(USD(-1))) & -0.094 \\
& $(0.074)$ \\
& {$[-1.271]$} \\
\hline
\end{tabular}

The short term dynamics, i. e. the error correction mechanism, is summarized in the next table including standard errors as well as $t$-statistics. The asterisk denotes rejection of the null hypothesis at the $10 \%$ level of significance.

Estimated model proves correspondence with the data of $45 \%(R$-squared $=0,445)$, and is overall statistically significant (F-statistic $=6,728$ ). The next figure shows the contributions of exogenous variables to the estimated year-on-year growth rates of domestic producer prices.

\section{Models of Export}

The variables analyzed in previous chapters can be used for the construction of several models of export dynamics which are in line with economic intuition and comply with statistical criteria. The models differ in particular in the exogenous variables standing for domestic and foreign price level. 


\subsection{Model with Producer Prices}

First some analysis is carried out to get the idea about the characteristics of used time series in subsequent regression.

In the table below the results of ADF test are summarized, and provide sufficient evidence, for it is not possible to reject the null hypothesis of unit root on reasonable significance level for all tested series. The ADF test is made under assumption of individual intercept and trend for examined series, and the lag length selection is based on modified SC. Nevertheless use of different lag length criteria (AIC, HQ) leads to similar outcome.

The time series are integrated of order one, $i$. e. I(1), as the ADF test of first differences in Table 17 proves, since it is possible to reject the null hypothesis of unit root on reasonable significance level for all examined series. The ADF test is made under precondition of individual intercept, while the trend is assumed to be eliminated by differencing. The lag length selection is again based on modified SC.

Table 17

Stationarity Test of the Logarithms of the Original Time Series and of the First Differences

\begin{tabular}{|l|c|c|l|c|c|}
\hline Series & Prob. & Lag & Series & Prob. & Lag \\
\hline LOG(X) & 0.826 & 1 & D(LOG(X)) & $0.005^{*}$ & 1 \\
\hline LOG(GDPEMU) & 0.901 & 0 & D(LOG(GDPEMU)) & $0.029^{*}$ & 2 \\
\hline LOG(PPIEMU) & 0.740 & 0 & D(LOG(PPIEMU)) & $0.018^{*}$ & 0 \\
\hline LOG(PPI) & 0.888 & 0 & D(LOG(PPI)) & $0.031^{*}$ & 1 \\
\hline LOG(EUR) & 0.255 & 0 & D(LOG(EUR)) & $0.000^{*}$ & 0 \\
\hline
\end{tabular}

According to the Granger causality with emphasis on the export $(X)$ the relations among the variables and their significance is included in the Table 18. It seems that rather changes in export precede changes in other variables. Relations among the series are not straightforward for purposes of the subsequent analysis, nevertheless in case of export some more complex interconnections could be expected.

Table 18

Granger Causality regarding $X$

\begin{tabular}{|l|c|c|}
\hline Null Hypothesis: & F-Statistic & Prob. \\
\hline LOG(GDPEMU) does not Granger Cause LOG(X) & 3.032 & 0.069 \\
\hline LOG(X) does not Granger Cause LOG(GDPEMU) & 5.765 & $0.001^{*}$ \\
\hline LOG(PPIEMU) does not Granger Cause LOG(X) & 4.922 & 0.051 \\
\hline LOG(X) does not Granger Cause LOG(PPIEMU) & 13.529 & $0.000^{*}$ \\
\hline LOG(PPI) does not Granger Cause LOG(X) & 3.226 & 0.052 \\
\hline LOG(X) does not Granger Cause LOG(PPI) & 13.229 & $0.000^{*}$ \\
\hline LOG(EUR) does not Granger Cause LOG(X) & 5.675 & $0.007^{*}$ \\
\hline LOG(X) does not Granger Cause LOG(EUR) & 7.850 & $0.001^{*}$ \\
\hline
\end{tabular}

The appropriate lag length used for Granger causality exploration was adjusted in line with the AIC, SC and HQ as it is summarized in the next table. The asterisk denotes the appropriate lag length. 
Table 19

Appropriate Lag Length Selection

\begin{tabular}{|l|l|l|l|}
\hline \multicolumn{1}{|c|}{ Lag } & AIC & SC & HQ \\
\hline $\mathbf{0}$ & -20.6 & -20.4 & -20.5 \\
\hline $\mathbf{1}$ & -28.8 & $-27.6^{*}$ & -28.3 \\
\hline $\mathbf{2}$ & -29.4 & -27.3 & -28.6 \\
\hline $\mathbf{3}$ & -30.0 & -26.9 & $-28.8^{*}$ \\
\hline $\mathbf{4}$ & -29.9 & -25.8 & -28.3 \\
\hline $\mathbf{5}$ & -29.7 & -24.7 & -27.8 \\
\hline $\mathbf{6}$ & $-30.7^{*}$ & -24.7 & -28.4 \\
\hline
\end{tabular}

As all the time series are of the same integration order, particularity I(1), the long-run dynamics can be inspected within the VECM, and some prior exploration of cointegration is necessary. The Johansen cointegration test is carried out again. Under the condition of intercept and trend the trace test as well as the maximum eigenvalue statistics gives the same outcome, as shown in Table 20. Both tests reject the null hypothesis of none cointegration rank on reasonable level of significance, and do not reject the null hypothesis of at most one cointegration rank at the same time. The asterisk denotes rejection of the null hypothesis at the $5 \%$ level of significance.

Table 20

Cointegration Rank Test (Trace and Maximum Eigenvalue)

\begin{tabular}{|l|r|r|r|r|r|r|c|}
\hline $\begin{array}{l}\text { Number of } \\
\text { hypothesized } \\
\text { cointegrating relations }\end{array}$ & Eigenvalue & $\begin{array}{c}\text { Trace } \\
\text { Statistic }\end{array}$ & $\begin{array}{l}\text { Critical } \\
\text { Value }\end{array}$ & Prob. & $\begin{array}{c}\text { Max-Eigen. } \\
\text { Statistic }\end{array}$ & $\begin{array}{l}\text { Critical } \\
\text { Value }\end{array}$ & Prob. \\
\hline None * & 0.612 & 86.167 & 69.819 & $0.001^{*}$ & 45.426 & 33.877 & $0.001^{*}$ \\
\hline At most 1 & 0.340 & 40.740 & 47.856 & 0.197 & 19.978 & 27.584 & 0.343 \\
\hline At most 2 & 0.246 & 20.762 & 29.797 & 0.373 & 13.555 & 21.132 & 0.403 \\
\hline At most 3 & 0.136 & 7.207 & 15.495 & 0.554 & 7.007 & 14.265 & 0.488 \\
\hline At most 4 & 0.004 & 0.201 & 3.841 & 0.654 & 0.201 & 3.841 & 0.654 \\
\hline
\end{tabular}

So, one cointegration relation can be estimated within the VECM. Since the variables are cointegrated, the Granger causality can be tested on levels, and it is assumed that the exogenity conditions are met. The lag length used in VECM estimation is set in line with the SC (Table 19). The numerical results regarding the export $(X)$ are shown below.

$\hat{\mathrm{D}}(\operatorname{LOG}(\mathrm{X}))=0.165 *(\operatorname{LOG}(\mathrm{X}(-1))+1.278 * \operatorname{LOG}($ GDPEMU$(-1))+3.167 * \operatorname{LOG}($ PPIEMU(-1) $)-$

- 7.672*LOG(PPI(-1)) + 2.619*LOG(EUR(-1)) + 0.014*TREND - 1.429) -

$-0.722 * \mathrm{D}(\operatorname{LOG}(\mathrm{X}(-1)))+1.996 * \mathrm{D}(\operatorname{LOG}(\operatorname{GDPEMU}(-1)))-0.211 * \mathrm{D}(\operatorname{LOG}(\operatorname{PPIEMU}(-1)))+$

$+0.715 * \mathrm{D}(\operatorname{LOG}(\operatorname{PPI}(-1)))+0.147 * \mathrm{D}(\operatorname{LOG}(\operatorname{EUR}(-1)))+0.025$

where the first non differenced terms express the long run relationship. Their statistical attributes are in the following table, where the standard errors are in brackets and $t$-statistics follow. The asterisk denotes rejection of the null hypothesis at the $10 \%$ level of significance. 
Table 21

Cointegrating Vector

\begin{tabular}{|l|c|}
\hline LOG $(X(-1))$ & 1.000 \\
\hline LOG(GDPEMU(-1)) & 1.583 \\
& $(1.316)$ \\
& {$[1.203]$} \\
\hline LOG(PPIEMU(-1)) & $3.668^{*}$ \\
& $(0.911)$ \\
& {$[4.024]$} \\
\hline LOG(PPI(-1)) & $-8.705^{\star}$ \\
& $(1.183)$ \\
& {$[-7.358]$} \\
\hline LOG(EUR(-1)) & $3.093^{*}$ \\
& $(0.535)$ \\
& {$[5.776]$} \\
\hline @TREND(95Q1) & $0.020^{\star}$ \\
& $(0.004)$ \\
\hline C & {$[4.089]$} \\
\hline
\end{tabular}

Table 22

Error Correction Mechanism

\begin{tabular}{|l|c|}
\hline CointEq1 & $0.155^{*}$ \\
& $(0.067)$ \\
& {$[2.308]$} \\
\hline D(LOG $(X(-1)))$ & $-0.724^{*}$ \\
& $(0.140)$ \\
& {$[-5.147]$} \\
\hline D(LOG(GDPEMU(-1))) & $1.961^{*}$ \\
& $(1.153)$ \\
& {$[1.703]$} \\
\hline D(LOG(PPIEMU(-1))) & -0.090 \\
& $(0.889)$ \\
& {$[-0.100]$} \\
\hline D(LOG(PPI(-1))) & 0.661 \\
& $0.879)$ \\
& {$[0.750]$} \\
\hline D(LOG(EUR(-1))) & 0.067 \\
& $(0.403)$ \\
& {$[0.16584]$} \\
\hline
\end{tabular}

The short term dynamics, $i . e$. the error correction mechanism, is summarized in Table 22 including standard errors and $t$-statistics.

The model proves a $46 \%$ correspondence with the data $(R$-squared $=0,463)$, and is overall statistically significant at $5 \%$ significance level $(F$-statistic $=6,191)$. The predictive ability of the model is shown in the following figure. Simulated ex-post predictions (Hušek, 2007) are made in one quarter distances for three quarters ahead from 2006Q1 onward.

Figure 4

Export ex-post Predictions

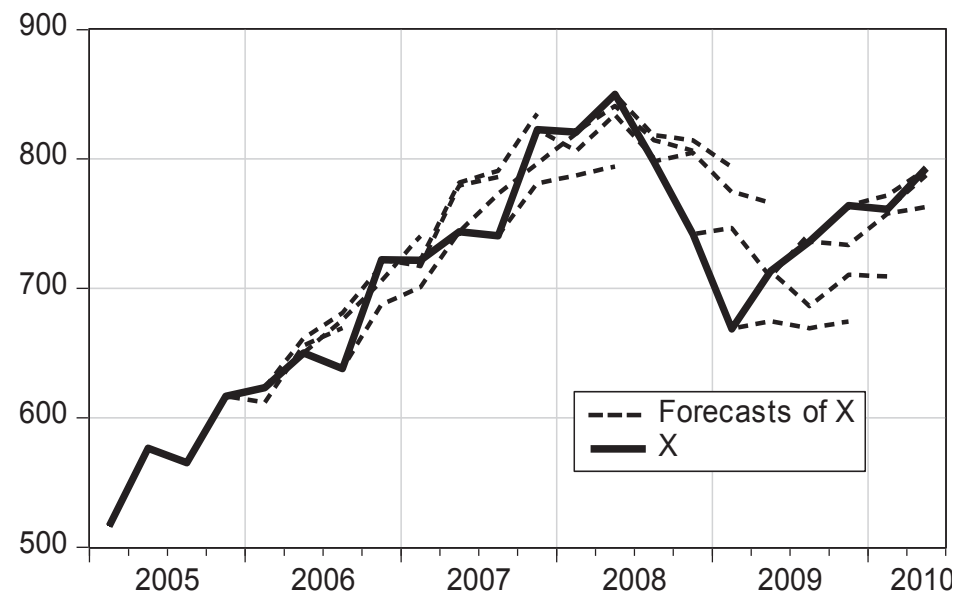




\subsection{Model with Import and Export Prices}

The cointegration analysis is carried out in a similar way as it was in the previous case. In the table below the results of ADF test are summarized, and provide sufficient evidence, for it is not possible to reject the null hypothesis of unit root on reasonable significance level for all tested series. The ADF test is made under assumption of individual intercept and trend for examined series, and the lag length selection is based on modified SC.

The time series are integrated of order one, as the ADF test of first differences in Table 23 shows, since it is possible to reject the null hypothesis of unit root on reasonable significance level for all examined series. The ADF test is made under precondition of individual intercept, while the trend is assumed to be eliminated by differencing. The lag length selection is again based on modified SC. Nevertheless use of other lag length criteria leads to similar conclusion. The asterisk denotes rejection of the null hypothesis at the $5 \%$ level of significance.

Table 23

Stationarity Test of the Logarithms of the Original Time Series and of the First Differences

\begin{tabular}{|l|c|c|l|c|c|}
\hline Series & Prob. & Lag & Series & Prob. & Lag \\
\hline LOG(X) & 0.826 & 1 & D(LOG(X)) & $0.005^{*}$ & $1^{*}$ \\
\hline LOG(GDPEMU) & 0.901 & 0 & D(LOG(GDPEMU)) & $0.029^{*}$ & $2^{*}$ \\
\hline LOG(DC) & 0.895 & 0 & D(LOG(DC)) & $0.004^{*}$ & 0 \\
\hline LOG(VC) & 0.614 & 0 & D(LOG(VC)) & $0.000^{*}$ & 0 \\
\hline LOG(EUR) & 0.255 & 0 & D(LOG(EUR)) & $0.000^{*}$ & 0 \\
\hline
\end{tabular}

The Granger causality outcome regarding the relation among variables with emphasis on the export $(X)$ is summarized in Table 24, and seems to be admissible, even though some of the are not directly convincing.

Table 24

Granger Causality regarding $X$

\begin{tabular}{|l|c|c|}
\hline Null Hypothesis: & F-Statistic & Prob. \\
\hline LOG(GDPEMU) does not Granger Cause LOG(X) & 3.032 & 0.059 \\
\hline LOG(X) does not Granger Cause LOG(GDPEMU) & 5.765 & $0.006^{*}$ \\
\hline LOG(DC) does not Granger Cause LOG(X) & 1.102 & $0.034^{*}$ \\
\hline LOG(X) does not Granger Cause LOG(DC) & 0.804 & 0.454 \\
\hline LOG(VC) does not Granger Cause LOG(X) & 1.105 & 0.141 \\
\hline LOG(X) does not Granger Cause LOG(VC) & 0.536 & 0.589 \\
\hline LOG(EUR) does not Granger Cause LOG(X) & 5.675 & $0.007^{*}$ \\
\hline LOG(X) does not Granger Cause LOG(EUR) & 7.850 & $0.001^{*}$ \\
\hline
\end{tabular}

The appropriate lag length used for Granger causality exploration was adjusted in line with the AIC, SC and HQ as it is summarized in the next table. 
Table 25

Appropriate Lag Length Selection

\begin{tabular}{|l|c|c|c|}
\hline Lag & AIC & SC & HQ \\
\hline $\mathbf{0}$ & -18.9 & -18.7 & -18.9 \\
\hline $\mathbf{1}$ & -28.1 & $-26.9^{*}$ & $-27.6^{*}$ \\
\hline $\mathbf{2}$ & -28.3 & -26.2 & -27.5 \\
\hline $\mathbf{3}$ & -28.2 & -25.1 & -27.0 \\
\hline $\mathbf{4}$ & -28.9 & -24.8 & -27.3 \\
\hline $\mathbf{5}$ & -28.9 & -23.9 & -27.0 \\
\hline $\mathbf{6}$ & $-28.9^{*}$ & -23.0 & -26.7 \\
\hline
\end{tabular}

All the series are of the same integration order, particularity I(1), so the long-run dynamics could be inspected within the VECM. Some prior exploration of cointegration is necessary, thus the Johansen cointegration test is carried out onward and summarized in Table 26. At the 5\% significance level the trace test suggests that there is at most one cointegrating relation, for it allows to reject the null hypothesis of none cointegration rank, and does not reject the null hypothesis of at most one cointegration rank at the same time. The maximum eigenvalue statistics suggests the same outcome at $10 \%$ level of significance, so the VECM can be estimated under the assumption of exogenity.

Table 26

Cointegration Rank Test (Trace and Maximum Eigenvalue)

\begin{tabular}{|l|r|r|r|r|r|r|r|}
\hline $\begin{array}{l}\text { Number of } \\
\text { hypothesized } \\
\text { cointegrating relations }\end{array}$ & Eigenvalue & $\begin{array}{c}\text { Trace } \\
\text { Statistic }\end{array}$ & $\begin{array}{l}\text { Critical } \\
\text { Value }\end{array}$ & Prob. & $\begin{array}{c}\text { Max-Eigen. } \\
\text { Statistic }\end{array}$ & $\begin{array}{c}\text { Critical } \\
\text { Value }\end{array}$ & Prob. \\
\hline None * & 0.493 & 71.373 & 69.819 & $0.037^{*}$ & 32.622 & 33.877 & $0.070^{*}$ \\
\hline At most 1 & 0.321 & 38.751 & 47.856 & 0.270 & 18.581 & 27.584 & 0.448 \\
\hline At most 2 & 0.221 & 20.170 & 29.797 & 0.411 & 12.002 & 21.132 & 0.547 \\
\hline At most 3 & 0.156 & 8.168 & 15.495 & 0.448 & 8.163 & 14.265 & 0.362 \\
\hline At most 4 & 0.000 & 0.005 & 3.841 & 0.941 & 0.005 & 3.841 & 0.941 \\
\hline
\end{tabular}

The statistical attributes of the long-run dynamics are in the following table, where the standard errors are in brackets and t-statistics follow. The asterisk denotes rejection of the null hypothesis at the $10 \%$ level of significance.

$\hat{\mathrm{D}}(\operatorname{LOG}(\mathrm{X}))=0.453 *(\operatorname{LOG}(\mathrm{X}(-1))-1.851 * \operatorname{LOG}(\mathrm{GDPEMU}(-1))+$

$+0.655 * \operatorname{LOG}(\mathrm{DC}(-1))-1.627 * \mathrm{LOG}(\mathrm{VC}(-1))+2.032 * \operatorname{LOG}(\mathrm{EUR}(-1)))-$

$-0.847 * \mathrm{D}(\mathrm{LOG}(\mathrm{X}(-1)))+2.756 * \mathrm{D}(\mathrm{LOG}(\mathrm{GDPEMU}(-1)))-$

$-0.085 * \mathrm{D}(\operatorname{LOG}(\mathrm{DC}(-1)))-0.287 * \mathrm{D}(\operatorname{LOG}(\operatorname{VC}(-1)))+0.532 * \mathrm{D}(\operatorname{LOG}(\operatorname{EUR}(-1)))$, 
Table 27

Cointegrating Vector

\begin{tabular}{|l|c|}
\hline LOG $(X(-1))$ & 1.000 \\
\hline LOG(GDPEMU(-1)) & $-7.195^{\star}$ \\
& $(3.765)$ \\
& {$[-1.910]$} \\
\hline LOG(DC(-1)) & $-4.405^{\star}$ \\
& $(2.742)$ \\
& {$[-1.606]$} \\
\hline LOG(VC(-1)) & $11.295^{\star}$ \\
& $(5.483)$ \\
& {$[2.060]$} \\
\hline LOG(EUR(-1)) & $-13.174^{*}$ \\
& $(2.958)$ \\
& {$[-4.453]$} \\
\hline @TREND(95Q1) & $-0.098^{*}$ \\
& $(0.017)$ \\
& {$[-5.483]$} \\
\hline C & 44.556 \\
\hline
\end{tabular}

Table 28

Error Correction Mechanism

\begin{tabular}{|l|c|}
\hline CointEq1 & $-0.106^{*}$ \\
& $(0.023)$ \\
& {$[-4.591]$} \\
\hline D(LOG $(X(-1)))$ & $-0.654^{*}$ \\
& $(0.109)$ \\
& {$[-5.974]$} \\
\hline D(LOG(GDPEMU(-1))) & $2.346^{*}$ \\
& $(0.98813)$ \\
\hline D(LOG(DC(-1))) & {$[2.374]$} \\
& -0.573 \\
& $(0.528)$ \\
\hline D(LOG(VC(-1))) & {$[-1.085]$} \\
& 0.457 \\
& $(0.883)$ \\
\hline D(LOG(EUR(-1))) & {$[0.517]$} \\
& -0.192 \\
& $(0.445)$ \\
& {$[-0.430]$} \\
\hline
\end{tabular}

The short term dynamics, i. e. the error correction mechanism, is summarized in Table 28 including standard errors and $t$-statistics.

The model proves a $60 \%$ correspondence with the data $(R$-squared $=0,596)$, and is overall statistically significant $(F$-statistic $=10,093)$. The predictive ability of the model is illustrated in the next figure of simulated ex-post predictions, which are made in one quarter distances for three quarters ahead.

Figure 5

Export ex-post Predictions

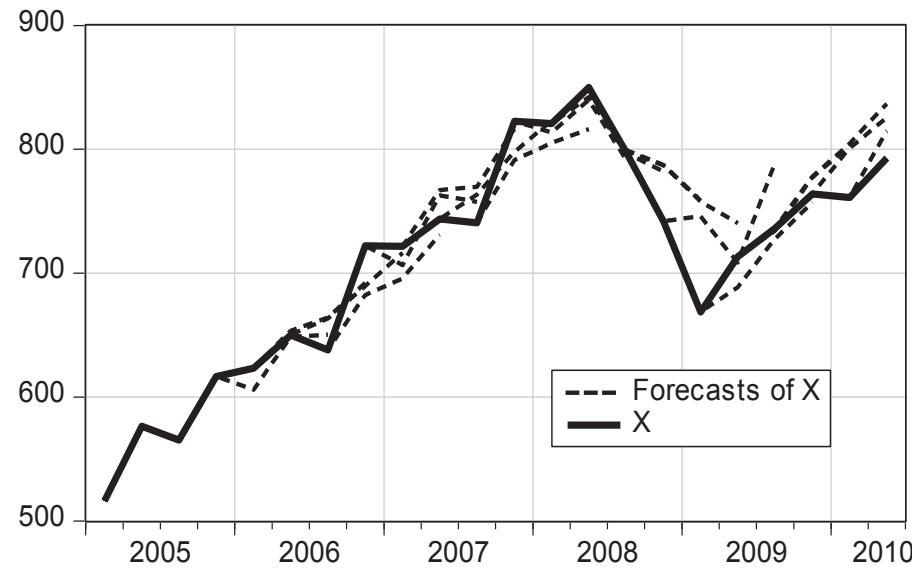




\subsection{Model with Consumer Prices}

If the foreign as well as the domestic prices are represented by consumer price levels, the directions of influences of exogenous variables remain unchanged; the lag of interactions is nevertheless shorter (Abdelhak and Montenegro, 1999).

The results of VECM are in this case unfortunately not intuitive, and the main reason can be seen in deficient cointegration dispositions of the data set. The domestic price level $(C P I)$ seems to be integrated of order two, i. e. I(2) as the next table summarizes. The asterisk denotes rejection of the null hypothesis of unit root at the $5 \%$ level of significance.

Table 29

Stationarity Test of the Logarithms of the Original Time Series and of the First Differences

\begin{tabular}{|l|c|c|l|c|c|}
\hline Series & Prob. & Lag & \multicolumn{1}{|c|}{ Series } & Prob. & Lag \\
\hline LOG(X) & 0.826 & 1 & D(LOG $(X))$ & $0.000^{*}$ & 2 \\
\hline LOG(GDPEMU) & 0.901 & 0 & D(LOG(GDPEMU)) & $0.000^{*}$ & 0 \\
\hline LOG(CPIEMU) & 0.968 & 0 & D(LOG(CPIEMU) $)$ & $0.000^{*}$ & 0 \\
\hline LOG(CPI) & 0.062 & 0 & D(LOG(CPI)) & 0.084 & 7 \\
\hline LOG(EUR) & 0.255 & 0 & D(LOG(EUR)) & $0.000^{*}$ & 1 \\
\hline
\end{tabular}

That makes the cointegration uneasy as the Johansen cointegration test in Table 30 shows. Under the assumption of intercept and trend the trace test as well as the maximum eigenvalue statistics give the same outcome, $i$. e. both tests suggest at most three cointegration ranks on reasonable level of significance.

Table 30

Cointegration Rank Test (Trace and Maximum Eigenvalue)

\begin{tabular}{|l|c|c|c|c|c|c|c|}
\hline $\begin{array}{l}\text { Number of } \\
\text { hypothesized } \\
\text { cointegrating relations }\end{array}$ & Eigenvalue & $\begin{array}{c}\text { Trace } \\
\text { Statistic }\end{array}$ & $\begin{array}{l}\text { Critical } \\
\text { Value }\end{array}$ & Prob. & $\begin{array}{c}\text { Max-Eigen. } \\
\text { Statistic }\end{array}$ & $\begin{array}{l}\text { Critical } \\
\text { Value }\end{array}$ & Prob. \\
\hline None * $^{*}$ & 0.555 & 115.545 & 76.973 & $0.000^{*}$ & 38.899 & 34.806 & $0.015^{*}$ \\
\hline At most 1 * & 0.496 & 76.646 & 54.079 & $0.000^{*}$ & 32.919 & 28.588 & $0.013^{*}$ \\
\hline At most 2 * & 0.415 & 43.727 & 35.193 & $0.005^{*}$ & 25.762 & 22.300 & $0.016^{*}$ \\
\hline At most 3 & 0.207 & 17.965 & 20.262 & 0.100 & 11.133 & 15.892 & 0.242 \\
\hline At most 4 & 0.133 & 6.832 & 9.165 & 0.136 & 6.832 & 9.165 & 0.136 \\
\hline
\end{tabular}

Nevertheless for purposes of the short-term analysis the CPI can be considered for I(1), while rejecting the null hypothesis of a unit root for the first difference of logarithms at $10 \%$ level of significance (Table 26), and en equation can be estimated onward.

In the next equation the role of foreign price level is taken by consumer prices in the European Union (CPIEMU), and domestic prices are represented by consumer prices in the Czech Republic $(C P I)$. There is again the foreign demand as foreign GDP (GDPEMU) and exchange rate (EUR). The equation is estimated on data with quarterly frequency for the period 1995Q3-2010Q2. The estimation is again carried 
out on differences of logarithms. The first differences of logarithms can be considered for stationary, even in case of the CPI. Consequently no problem of spurious regression as well as heteroskedasticity is expected.

$\operatorname{DLOG}(\mathrm{X})=\mathrm{C}(1)+\mathrm{C}(2) * \operatorname{DLOG}(\mathrm{X}(-1))+\mathrm{C}(3) * \mathrm{DLOG}(\mathrm{GDPEMU})+$ $+\mathrm{C}(4) * \operatorname{DLOG}($ CPIEMU) $+\mathrm{C}(5) * \operatorname{DLOG}(\mathrm{CPI})+\mathrm{C}(6) * \mathrm{DLOG}(\mathrm{EUR}(-1))+\mathrm{u}$,

and after the parameters are estimated

$\operatorname{DLÔG}(\mathrm{X})=-0.011-0.595 * \operatorname{DLOG}(\mathrm{X}(-1))+3.939 * \mathrm{DLOG}(\mathrm{GDPEMU})+$

$+7.332 *$ DLOG(CPIEMU) $-1.509 * \mathrm{DLOG}(\mathrm{CPI})+0.586 * \operatorname{DLOG}(\mathrm{EUR}(-1))$.

The table bellow displays basic statistic. The asterisk denotes rejection of the null hypothesis at the $5 \%$ level of significance.

Table 31

Basic Statistics of the Export Equation

\begin{tabular}{|l|c|c|c|c|c|}
\hline C1 & C2 & C3 & C4 & C5 & C6 \\
\hline$-\mathbf{0 . 0 1 1}$ & $-0.595^{*}$ & $3.939^{*}$ & $7.332^{*}$ & $-1.509^{*}$ & $0.586^{*}$ \\
$\mathbf{( 0 . 0 1 3 )}$ & $(0.095)$ & $(0.707)$ & $(2.202)$ & $(0.532)$ & $(0.211)$ \\
{$[-0.872]$} & {$[-6.214]$} & {$[5.568]$} & {$[3.328]$} & {$[-2.834]$} & {$[2.769]$} \\
\hline
\end{tabular}

Modelling export dynamics with the consumer prices improves the congruence of the estimate to $63 \%(R$-squared $=0,627)$. The estimate has an overall statistical significance $(F$-statistic $=18,159)$, and individual parameters are statistically significant at least at $5 \%$ level of significance. The economic assumptions are satisfied.

The forecasting performance of the model is shown in the following figure. Simulated ex-post predictions are again carried out in one quarter distances for three quarters ahead. It is obvious that the model with consumer prices has got the best forecasting performance.

Figure 6

Export ex-post Predictions

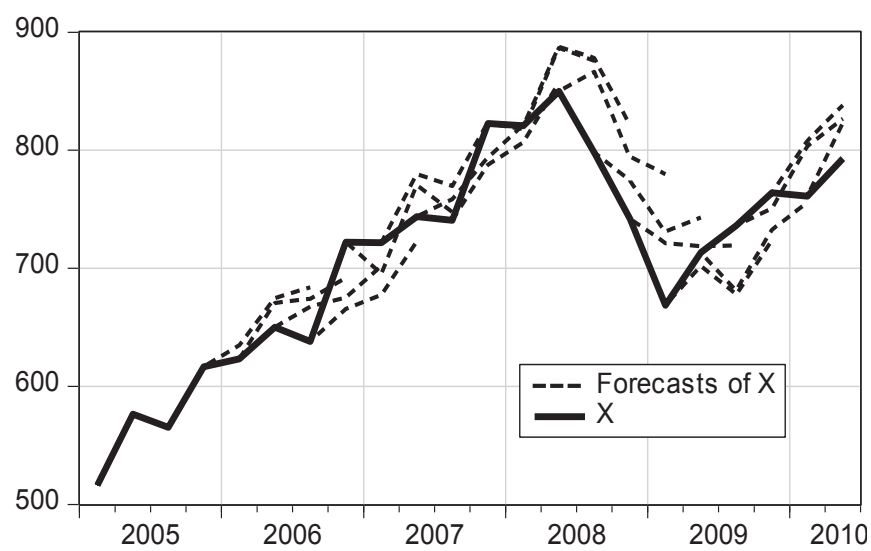




\section{Conclusion}

All of the above-mentioned export models confirm macroeconomic relations between export dynamics, development of foreign demand, domestic and foreign price levels and exchange rate. The model with consumer prices is the most appropriate for prediction, while the models with producer prices and import and export prices have higher analytical value.

The exchange rate appreciation leads to a decrease in import prices, which lowers the costs of domestic producers. On the other hand, the export model shows that the increase of import prices leads to the increase of export, probably because the import prices are mainly driven by world prices of crude materials and semi-finished products - this cost factors can be considered for almost the same in both foreign and domestic economy. It seems that the Czech exporters cope better with price increase of crucial inputs on world markets. Furthermore, the rise of import prices reduces the import dynamics, and the net export consequently increases. This is, nevertheless, not that straightforward in the case of the Czech Republic, where the export is significantly import-intensive, and exports are highly correlated with imports.

At the same time export dynamics decreases with exchange rate appreciation. Exchange rate movement therefore works as a stabilizer of producer costs as well as of export dynamics. Thus in case of noticeably growing prices of crude materials and semi-finished products in the world markets, exchange rate appreciation usually buffers the growth of domestic producer cost factors on the one hand, and reduces export growth directly through higher prices of exported goods in foreign currency on the other hand. While the domestic producer costs lower, the exports prices increase. This leads to stabilization of export dynamics through exchange rate movements. The importance of this buffering effect rises as the volatility of world prices of crude materials increases.

\section{References}

Abdelhak Senhadji, A. S., Montenegro, C. (1999), "Time Series Analysis of Export Demand Equations: A Cross-Country Analysis." IMF Working Paper.

Akaike, H. (1969), "Fitting Autoregressions for Prediction." Annals of the Institute of Statistical Mathematics, 21 (2), pp. 243-247.

Čihák M., Holub, T. (2000), "Cenová konvergence k Evropské unii - problém relativních cen." Politická ekonomie, Vol. 48, No.5, pp. 214-226.

Davidson, R., MacKinnon, J. G. (2004), Econometric Theory and Methods. Oxford University Press.

Dickey, D. A., Fuller, W. A. (1979), "Distribution of Estimators for Autoregressive Time Series with a Unit Root." Journal of American Statistical Association, Vol. 74, No. 366, pp. 427-431.

Elliott, G., Rothenberg, T. J., Stock, J. H. (1996), "Efficient Tests for an Autoregressive Unit Root." Econometrica, 64 (4), pp. 813-836.

Enders, W. (2004), Applied Econometric Time Series, 2nd Ed. John Wiley \& Sons, Inc.

Engle, R. F., Granger,C. W. J. (1987), “Cointegration and Error Correction: Representation, Estimation and Testing." Econometrica, Vol. 55, No. 2, pp. 251-276.

Frenkel, J. A. (1981), "Flexible Exchange Rates, Prices and the Role of News: Lessons from the 1970s." Journal of Political Economy, Vol. 89, No. 4, pp. 665-705. 
Greene, W. H. (2003), Econometric Analysis, 5th Ed. New Jersey: Prentice Hall.

Geweke, J. (1984), Inference and Causality in Economic Time Series Models. Handbook of Econometrics. Elsevier Science Publishers BV.

Granger, C. W. J., Newbold, P. (1974), "Spurious Regressions in Econometrics." Journal of Econometrics, Vol. 2, No. 2, pp. 111-120.

Hamilton, J. D. (1994), Time Series Analysis. New Jersey: Princeton University Press.

Hannan, E. J., Quinn, B. G. (1979), "The Determination of the Order of an Autoregression." Journal of the Royal Statistical Society B, Vol. 41, No. 2, pp. 190-95.

Hušek, R. (2007), Ekonometrická analýza. Praha: Oeconomica.

Johansen, S., Juselius, K. (1990), "Maximum Likelihood Estimation and Inference on Cointegration - With Application on Demand for Money." Oxford Bulletin of Economics and Statistics, 52, pp. 169-210.

Johansen, S. (1988), "Statistical Analysis of Cointegrating Vectors." Journal of Economic Dynamics and Control, 12, pp. 231-254.

Nešvera, V. (2006), “Ceny v obchodě České republiky se zeměmi Evropské unie." Politická ekonomie, Vol. 54, No. 2, pp. 214-226

Norman, D. (2006), "Modelling Manufactured Exports: Evidence from Australian States." Reserve Bank of Australia.

Pánková, V. (2003), "Analýza vlivu cenových relací na objem exportu v České republice." Politická ekonomie, Vol. 51, No. 4, pp. 533-515

Rogoff, K. (1996), “The Purchasing Power Parity Puzzle.” Journal of Economic Literature, 34 (2), pp. 647-668.

Rojíček, M. (2010), "Konkurenceschopnost obchodu ČR v procesu globalizace." Politická ekonomie, Vol. 58, No. 2, pp. 147-105

Tichý, F. (2007), "Impact of Accession to EMU on International Trade - Case of the Czech Republic." Prague Economic Papers, Vol. 16, No. 4, pp. 336-346

Williams, J. C., Wright, B. D. (1991), Storage and Commodity Markets. Cambridge: Cambridge University Press.

Wooldridge, J. M. (2002), Introductory Econometrics, 2nd Ed. South-Western College Publishing.

Xu, Z. (1999), "The Exchange Rate and Long-Run Price Movements in the US and Japan." Applied Economics Letters, 6 (4), pp. 227-230.

Zweimüller, J. (2001), Open Economy Macroeconomics. Zurich: University of Zurich. 